\title{
ENVIRONMENTAL ASSESSMENT FOR THE OFF-SITE VOLUME REDUCTION OF LOW-LEVEL RADIOACTIVE WASTE FROM THE SAVANNAH RIVER SITE
}

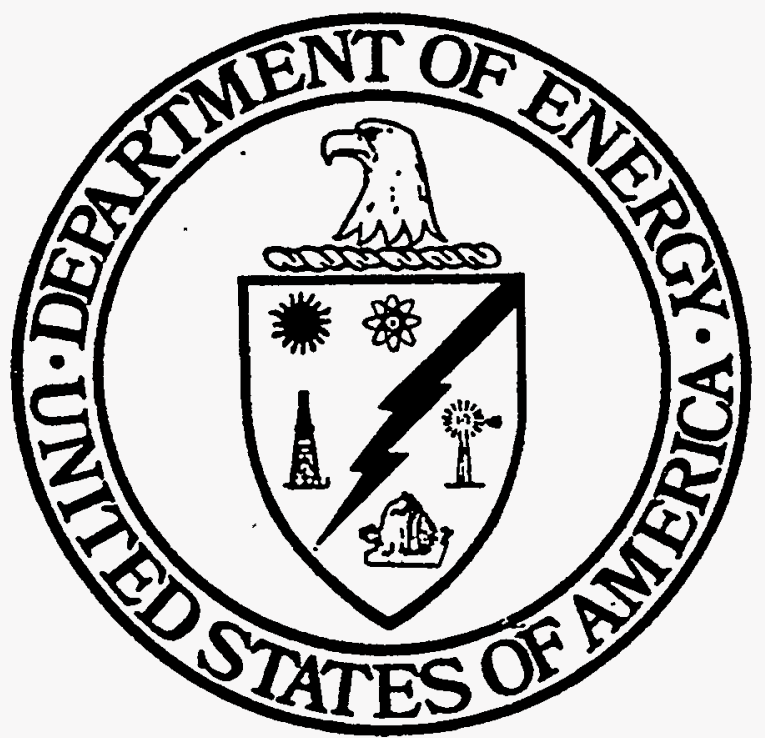

$$
\begin{aligned}
& \text { RECEIVED } \\
& \text { JAN } 3113410 \\
& \text { OSTI }
\end{aligned}
$$

JULY 1995

\section{U. S. DEPARTMENT OF ENERGY SAVANNAH RIVER OPERATIONS OFFICE SAVANNAH RIVER SITE}




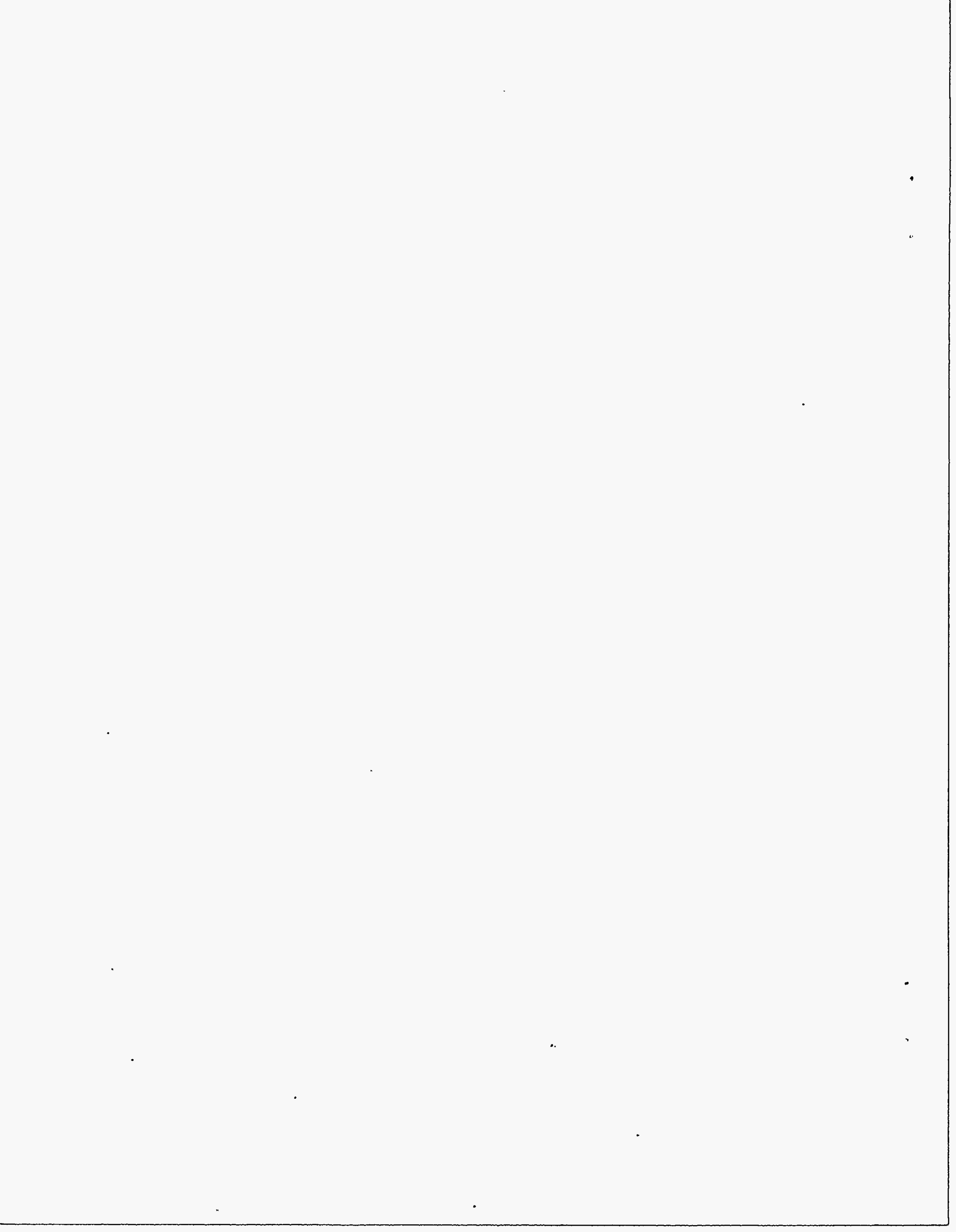


Finding of No Significant Impact

Off-Site Volume Reduction of

Low-Level Radioactive Waste .

from the Savannah River Site
RECEIVED

JAN 311996

OSTI
Agency:
U. S. Department of Energy
Action:
Finding of No Significant Impact

Summary: The Department of Energy (DOE) has prepared an environmental assessment (EA) (DOE/EA-1061) for the proposed off-site volume reduction of low-level radioactive wastes (LLW) generated at the Savannah River Site (SRS), near Aiken, South Carolina. Based on the analyses in the EA, DOE has determined that the proposed action is not a major Federal action significantly affecting the quality of the human environment within the meaning of the National Environmental Policy Act (NEPA) of 1969. Therefore, the preparation of an environmental impact statement (EIS) is not required, and DOE is issuing this Finding of No Significant Impact (FONSI).

\section{Public Availability:}

Copies of the EA and FONSI or further information on the DOE NEPA process are available from:
A. R. Grainger
SR NEPA Compliance Officer
Environmental Compliance Division
Savannah River Operations Office
P. O. Box 5031
Aiken, South Carolina 29804
Phone/FAX: (800) 242-8269
E-mail: nepa@barmS036.b-r.com

Background: The LLW generated by SRS facilities is composed of a wide variety of waste forms including job control waste, lumber, debris, and equipment which can be contaminated with fission products, activated metals, and/or Special Nuclear Materials. The Site presently generates approximately 17,900 cubic meters $(630,000$ cubic feet) of uncompacted LLW on an annual basis. SRS compacts as much of this waste as possible to more efficiently use the Site's remaining vault disposal capacity. However, because of radionuclide content and physical constituents, the existing Site compactor located in H Area can only accept approximately 25 percent of this waste for volume reduction. Based on the SRS waste generation forecast, it is expected that the existing E-Area Vault will reach capacity by 1997. At present, DOE does not plan to construct and operate any additional vaults for LLW disposal at SRS. Therefore, it is essential to use the remaining vault capacity as efficiently as possible. To that end, all LLW to be disposed of in the E-Area Vault needs to be volume reduced prior to disposal.

Over the next six months (i.e., mid-July 1995 through mid-January 1996), the subject 75 percent of the SRS LLW volume which could not be treated on site would encompass approximately 4,503 cubic meters $(159,000$ cubic feet). This represents less than three percent of the total LLW volume being considered for off-site vendor treatment within the SRS Waste Management EIS. Long-term (i.e., 30 year time frame) alternative solutions to this treatment/disposal issue are being evaluated as a component of that EIS.

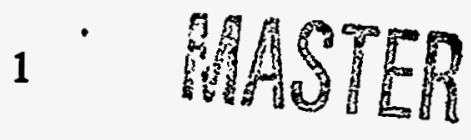




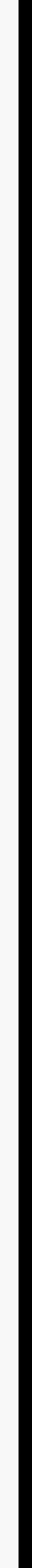


The purpose of the proposed action is to provide SRS with an interim means of volume reducing the Site-generated LLW prior to finalization and issuance of the SRS Waste Management EIS and associated Record of Decision. Because of the limited vault disposal capacity for LLW at SRS, DOE needs to take action to volume reduce all of the subject waste in the most expedient and cost-effective manner over the near-term time frame prior to disposal in the E-Area Vault. Such an action would not limit the ultimate choice of reasonable alternatives under consideration in this EIS and, as such, would qualify as an interim action under both the Council on Environmental Quality regulations and DOE regulations for the implementation NEPA.

Proposed Action: The proposed action is to volume reduce approximately 4,503 cubic meters of SRS-generated LLW at an off-site vendor facility with all required Nuclear Regulatory Commission, state, and local licenses and/or permits, and then dispose of the treated LLW in the E-Area Vault. The scope of the proposed action within this EA would be implemented between mid-July 1995 through mid-January 1996 and encompasses two specific LLW treatment initiatives at SRS including: (1) Interworks Requisition; and (2) Vendor Forum. The Interworks Requisition initiative would involve transport of LLW off site by a commercial vendor, treatment by compaction and/or decontamination at the vendor's facility, and shipment back to SRS to dispose in the E-Area Vault. The Vendor Forum initiative would be accomplished by waste segregation on site, transportation off site to a vendor treatment facility, treatment, repackaging, and transportation back to SRS. Other activities would include sorting, monitoring for cross contamination, containerization, and transportation of the primary treated LLW in Department of Transportation strong-type containers back to SRS for disposal in the E-Area Vault. Decontaminated metals would be free released and become the property of the vendor. Decontamination solutions including removed radionuclides would also become the property of the vendor. The total volume of LLW encompassed by the proposed action would fill approximately 1,600 B-25 boxes. There would be an estimated 89 shipments off site. Following vendor treatment, the volume-reduced LLW would be returned to SRS. It is estimated that there would be a total of 56 return shipments to SRS, each carrying a maximum of 12 overpacks. The total cost of vendor treatment off site with on-site disposal is estimated at $\$ 1,183,000$.

The vendor will be responsible for providing all vehicles, containers, equipment, security and health and safety requirements to return the waste to SRS. The vendor is responsible for all Federal, state, and local licenses, permits, and other required documentation to treat LIW and for ensuring that all Department of Transportation, and DOE regulations and orders are met for LLW shipments. DOE will ensure that external contamination to the containers leaving SRS does not exceed Department of Transportation limits or those documented in DOE Radiological Control Manual and the Site radiological control manual. Wastes shipped off site by the vendor will be certified in accordance with Site requirements and have sufficient certification documentation and radioisotopic information to comply with the Waste Acceptance Criteria for the E-Area Vault and the vendor's facility operation. Site personnel will be responsible for loading the waste into the B-25 boxes and the vendor will take custody of the packaged LLW at the waste staging area in E Area and transport the waste shipments to the vendor's off-site facility. DOE will take custody of the treated waste from the vendor at SRS's waste receiving area.

Alternatives: In addition to the proposed action, DOE considered the following alternatives: (1) No Action (i.e., continue to use existing H-Area compactor and store in E-Area Vault); (2) modify and expand the capacity of the H-Area compactor, and, (3) construct a new waste preparation facility at SRS. The no-action alternative would continue to fill the E-Area Vault during the near-term at an economically unattractive 

rate: The no-action alternative is therefore not a reasonable alternative, but was analyzed for baseline purposes. The impacts of the two reasonable alternatives that will meet the need for DOE action were analyzed. These alternatives were not selected for the following stated reasons. The alternative to modify the existing H-Area compactor was estimated to cost $\$ 750,000$ and would still result in the use of outdated low-force compaction technology, would not allow volume reduction of all waste streams, and would not provide the full range of capabilities of the off-site commercial facilities. In addition, this alternative could not be implemented within the subject time frame associated with the proposed action. This alternative was judged to be both economically and logistically unfeasible. The third alternative, to construct a new waste preparation facility to provide volume reduction capacity for the site, would not match the capabilities available at off-site commercial facilities. Furthermore, this alternative is estimated to cost approximately $\$ 54$ million dollars and would not be operational within the near-term time frame being considered for the proposed action. As with the previous alternative, this alternative was determined to be both economically and logistically unfeasible.

Environmental: The potential consequences of the proposed off-site volume reduction of SRS-generated LLW were assessed to determine whether there will be significant impact to the following: water, air, and land resources; floodplains and wetlands; ecological and cultural resources; health and safety; socioeconomic conditions; and transportation. The proposed action would not result in the loss of any lands on SRS. There are no impacts expected to occur to wetlands or sensitive ecological habitats, threatened or endangered species, or cultural resources. Aside from the existing impacts associated with ongoing operations at the Solid Waste Management Facility, no additional impacts are projected for surface water, ground water or air resources. Once implemented, the on-site operations would be staffed of personnel who are already employed in the Solid Waste Management Facility. Workers engaged in this proposed project would not be expected to incur any harmful health effects from radiation exposures received during normal operations. The transportation impacts were determined for the off-site shipment of the SRS generated LLW to Oak Ridge, Tennessee, for treatment/volume reduction and return to SRS. Both incident-free and accident radiological impacts for the LLW shipments were analyzed. No latent fatal cancers would be expected to result from the implementation of the proposed action.

Determination: Based on the information and analyses in the EA, DOE has determined that the proposed off-site volume reduction by means of supercompaction, metal melt and/or decontamination of LLW generated at SRS does not constitute a major Federal action significantly affecting the quality of the human environment with the meaning of NEPA. Therefore, an EIS is not required and DOE is issuing this FONSI.

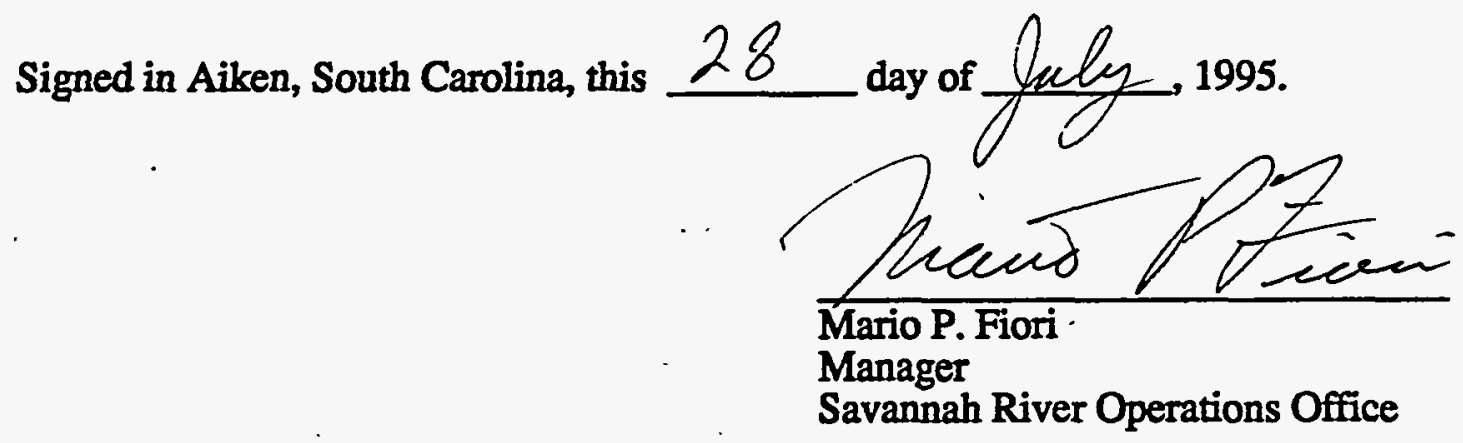





\section{ENVIRONMENTAL ASSESSMENT FOR THE OFF-SITE VOLUME REDUCTION OF LOW-LEVEL RADIOACTIVE WASTE FROM THE SAVANNAH RIVER SITE}

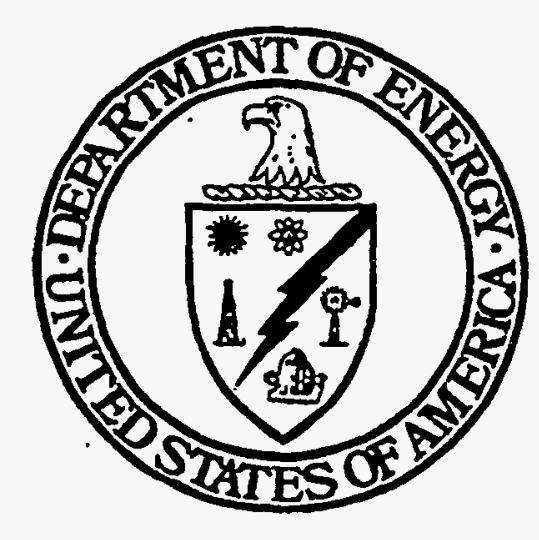

\section{JULY 1995}

UNITED STATES DEPARTMENT OF ENERGY SAVANNAH RIVER OPERATIONS OFFICE SAVANNAH RIVER SITE 


\section{TABLE OF CONTENTS}

1.0 INTRODUCTION 1

1.1 Background 1

1.2 Purpose and Need for Action 1

2.0 PROPOSED ACTION AND ALTERNATIVES 3

2.1 Proposed Action 3

2.2 Alternatives to the Proposed Action 5

2.2.1 No Action, Continue to Use the Existing H-Area Compactor and/or Dispose in E-Area Vault

2.2.2 Modify and Expand the Capacity of the H-Area Compactor

2.2.3 Construct a New Waste Preparation Facility

3.0 ENVIRONMENTAL CONSEQUENCES OF THE PROPOSED ACTION AND ALTERNATIVES

3.1 Vendor Facility Operation

3.2 SRS Waste Management Facility Operations

3.3 Transportation Impacts

3.3.1 Analyzed Scenario

3.3.2 Assumptions

3.3.3 Radiological Consequences

3.4 Environmental Consequences of the Alternatives 11

3.5 Cumulative Impacts 12

4.0 REGULATORY AND PERMITTING PROVISIONS CONSIDERED 12

4.1 National Environmental Policy Act of 1969 as amended 12

4.2 Waste Shipment Regulations 13

4.3 Site LLW Regulations 13

$\begin{array}{lll}5.0 & \text { REFERENCES } & 14\end{array}$ 


\section{LIST OF TABLES}

Table 1. Shipping Configurations and Number of Shipments by Waste Form.

Table 2. Route Information, SRS to Oak Ridge, Tennessee (from HIGHWAY).

Table 3. Incident-Free Transportation Impacts for LLW Shipments by Truck from and returning to SRS.

Table 4. Transportation Accident Impacts for LLW Shipments by Truck from and returning to SRS.

Table 5. Number of Latent Cancer Fatalities for Incident-Free Transportation of LLW Shipments from and to SRS.

Table 6. Maximum Number of Potential Latent Cancer Fatalities from Accidents for LLW Shipments from and to SRS.

\section{LIST OF FIGURES}

Figure 1. Location of the H-Area Compactor and the Solid Waste Management

Facility at the Savannah River Site, South Carolina.

Figure 2. Flowchart of the overall process for the proposed action. 


\subsection{INTRODUCTION}

This Environmental Assessment (EA) has been prepared by the Department of Energy (DOE) to assess the potential environmental impacts of off-site volume reduction of low-level radioactive wastes (LLW) generated at the Savannah River Site (SRS), located near Aiken, South Carolina (Figure 1). The proposed action would involve the transport of the SRS-generated LLW to an off-site vendor facility, treatment of these wastes by means of supercompaction, metal melt and/or decontamination at that facility, and then return shipment of the volume-reduced waste to the Site for disposal. This action would further be implemented within the near term six-month time frame as an interim action to the SRS Waste Management Environmental Impact Statement (EIS) (DOE/EIS-217D) under the National Environmental Policy Act of 1969 (NEPA).

\subsection{Background}

The LLW generated by SRS facilities is composed of a wide variety of waste forms including job control waste, lumber, debris, and equipment which can be contaminated with fission products, activated metals, and/or Special Nuclear Materials. The Site presently generates approximately 17,900 cubic meters $(630,000$ cubic feet) of uncompacted LLW (i.e., solid waste that radiates less than 200 millirem per hour at 5 centimeters or 2 inches from the unshielded container) on an annual basis (DOE, 1995). SRS compacts as much of this waste as possible to more efficiently use the Site's remaining vault disposal capacity. However, because of radionuclide content and physical constituents, the existing Site compactor located in H Area can only accept approximately 25 percent of this waste for volume reduction. Based on the SRS waste generation forecast (WSRC, 1994a), it is expected that the existing E-Area Vault will reach capacity by 1997 . At present, DOE does not plan to construct and operate any additional vaults for LLW disposal at SRS. Therefore, it is essential to use the remaining vault capacity as efficiently as possible. To that end, all LLW to be disposed of in the E-Area Vault needs to be volume reduced prior to disposal.

Over the next six months (i.e., mid-July 1995 through mid-January 1996), the subject 75 percent of the SRS LLW volume which could not be.treated on site would encompass approximately 4,503 cubic meters $(159,000$ cubic feet). This represents less than three percent of the total LLW volume being considered for off-site vendor treatment within the SRS Waste Management EIS (DOE, 1995). Long-term (i.e., 30 year time frame) alternative solutions to this treatment/disposal issue are being evaluated as a component of that EIS. Within the near term, modifications to the existing H-Area compactor or construction of a new compactor facility at SRS to provides all of the volume reduction capabilities of existing off-site commercial facilities would be logistically difficult to implement in a timely manner. In order to minimize the near-term disposal capacity utilization of the E-Area Vault, off-site volume reduction was selected as a viable interim action awaiting issuance of a Record of Decision (ROD) for the Waste Management EIS. Such an action would not limit the ultimate choice of reasonable alternatives under consideration in this EIS, and, as such, would qualify as an interim action under both the Council on Environmental Quality (CEQ) regulations (40 CFR 1506.1) and DOE regulations (10 CFR 1021.211) for the implementation NEPA.

\subsection{Purpose and Need for Action}

The purpose of the proposed action is to provide SRS with an interim means of volume reducing the Site-generated LLW prior to finalization and issuance of the SRS Waste Management.EIS and associated ROD. Because of the limited vault disposal capacity for LLW at SRS, DOE needs to take action to volume reduce all of the subject waste in the most expedient and cost-effective manner over the near-term time frame prior to disposal in the E-Area Vault Deferring a decision until issuance of a ROD for the aforementioned EIS would not enable the most effective use of the available disposal capacity remaining in the E-Area Vault within the subject time frame. 


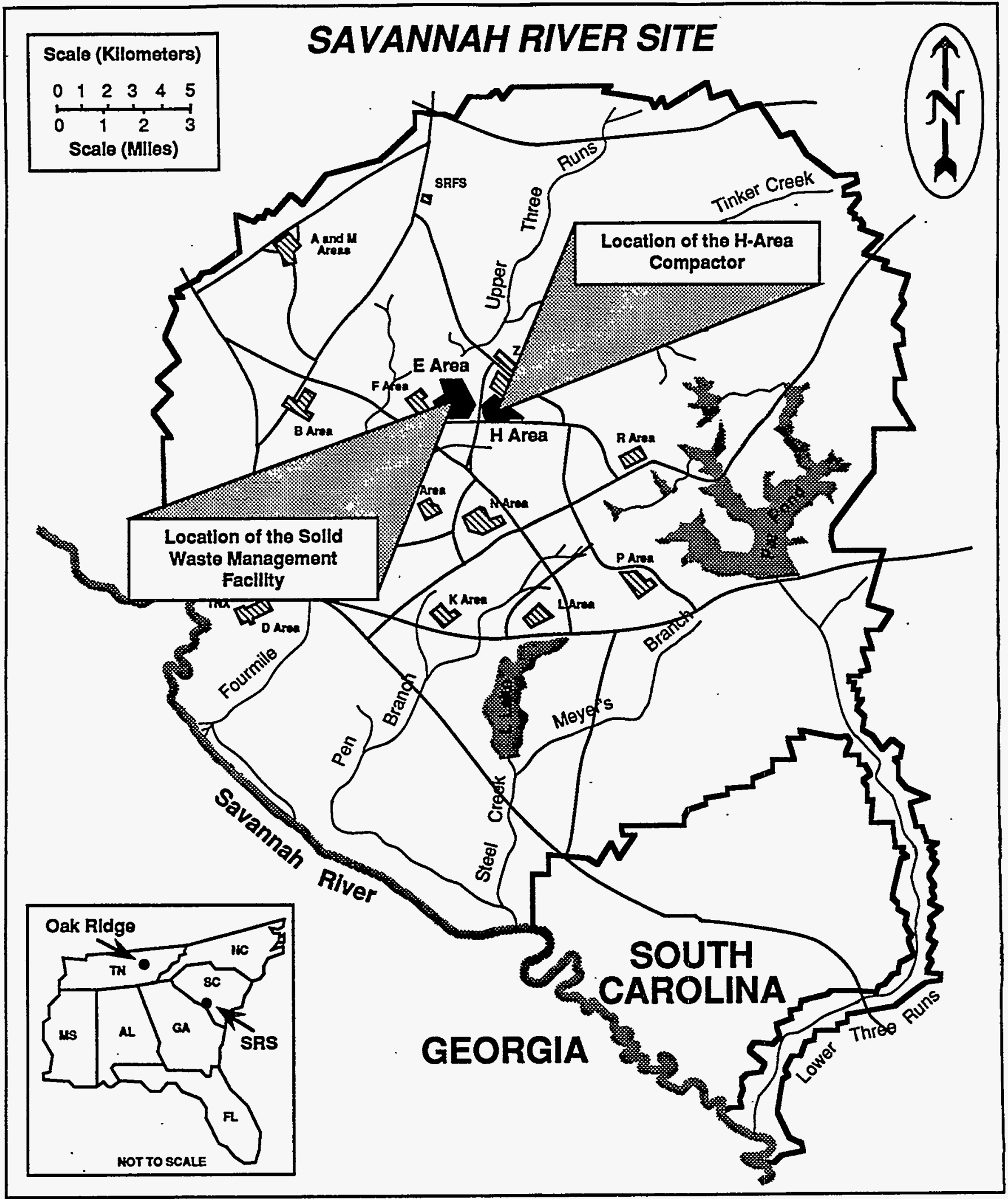

Figure 1. Location of the H-Area Compactor and the Solid Waste Management Facility at the Savannah River Site, South Carolina. 


\subsection{PROPOSED ACTION AND ALTERNATIVES}

\subsection{Proposed Action}

The proposed action is to volume reduce approximately 4,503 cubic meters $(159,000$ cubic feet) of SRS-generated LLW at an off-site vendor (subcontractor) facility with all required Nuclear Regulatory Commission (NRC), state, and local licenses and/or permits, and then dispose of the treated LLW in the E-Area Vault. The scope of the proposed action within this EA would be implemented over a six-month period of time (i.e., mid-July 1995 through mid-January 1996) and encompasses two specific LLW treatment initiatives at SRS including: (1) Interworks Requisition (IWR); and (2) Vendor Forum (VF). The IWR initiative would involve transport of LLW off site by a commercial vendor, treatment by compaction and/or decontamination at the vendor's facility, and shipment back to SRS to dispose in the E-Area Vault. The VF initiative would be accomplished by waste segregation on site, transportation off site to a vendor treatment facility, treatment, repackaging (i.e., slag from metal melting, and super-compacted materials), and transportation back to SRS. Other activities would include sorting, monitoring for cross contamination, containerization, and transportation of the primary treated LLW in Department of Transportation (DOT) strong-type containers back to SRS for disposal in the E-Area Vault. Decontaminated metals would be free released and become the property of the vendor. Decontamination solutions including removed radionuclides would also become the property of the vendor. The total cost of vendor treatment off site with on-site disposal is estimated at $\$ 1,183,000$.

The proposed overall (i.e., combined IWR/VF initiatives) process associated with the proposed action, including packaging of the LLW at SRS, transportation to an off-site vendor treatment facility, and return to SRS for disposal in the E-Area Vault, is shown in Figure 2. The total volume reduction service is estimated to be 4,503 cubic meters $(159,000$ cubic feet) over a six-month time frame. This would fill approximately 1,600 B-25 boxes ( 2.55 cubic meters or 90 cubic feet each). There would be an estimated 89 shipments off site. SRS would ensure that LLW shipped to an offsite vendor for treatment would not exceed that facility's waste acceptance criteria.

Following vendor treatment, the volume-reduced LLW would be returned to SRS. It is estimated that there would be a total of 56 return shipments to SRS, each carrying a maximum of 12 overpacks (each overpack contains approximately $80 \mathrm{cu}$. ft. of wastes). The unshielded dose for return shipments would not exceed $<200 \mathrm{mrem} / \mathrm{hr}$ on contact.

The vendor will be responsible for providing all vehicles, containers, equipment, security and health and safety requirements to return the waste to SRS. The vendor is responsible for all Federal, state, and local licenses, permits, and other required documentation to treat LLW and for ensuring that all DOT, and DOE regulations and orders are met for LLW shipments. DOE will ensure that external contamination to the containers leaving SRS does not exceed DOT limits or those documented in DOE Radiological Control Manual (DOE, 1994a) and the WSRC 11Q Manual (WSRC, 1990). Wastes will be packaged in B-25 boxes. Wastes shipped off site by the vendor will be certified in accordance with the WSRC 1S Manual (WSRC, 1993) and have sufficient certification documentation and radioisotopic information to comply with the Waste Acceptance Criteria for the E-Area Vault and the vendor's facility operation.

Site personnel will be responsible for loading the waste into the B-25 boxes and the vendor will take custody of the packaged LLW at the waste staging area in E Area and transport the waste shipments to the vendor's off-site facility. DOE will take custody of the treated waste from the vendor at SRS's. waste receiving area. 


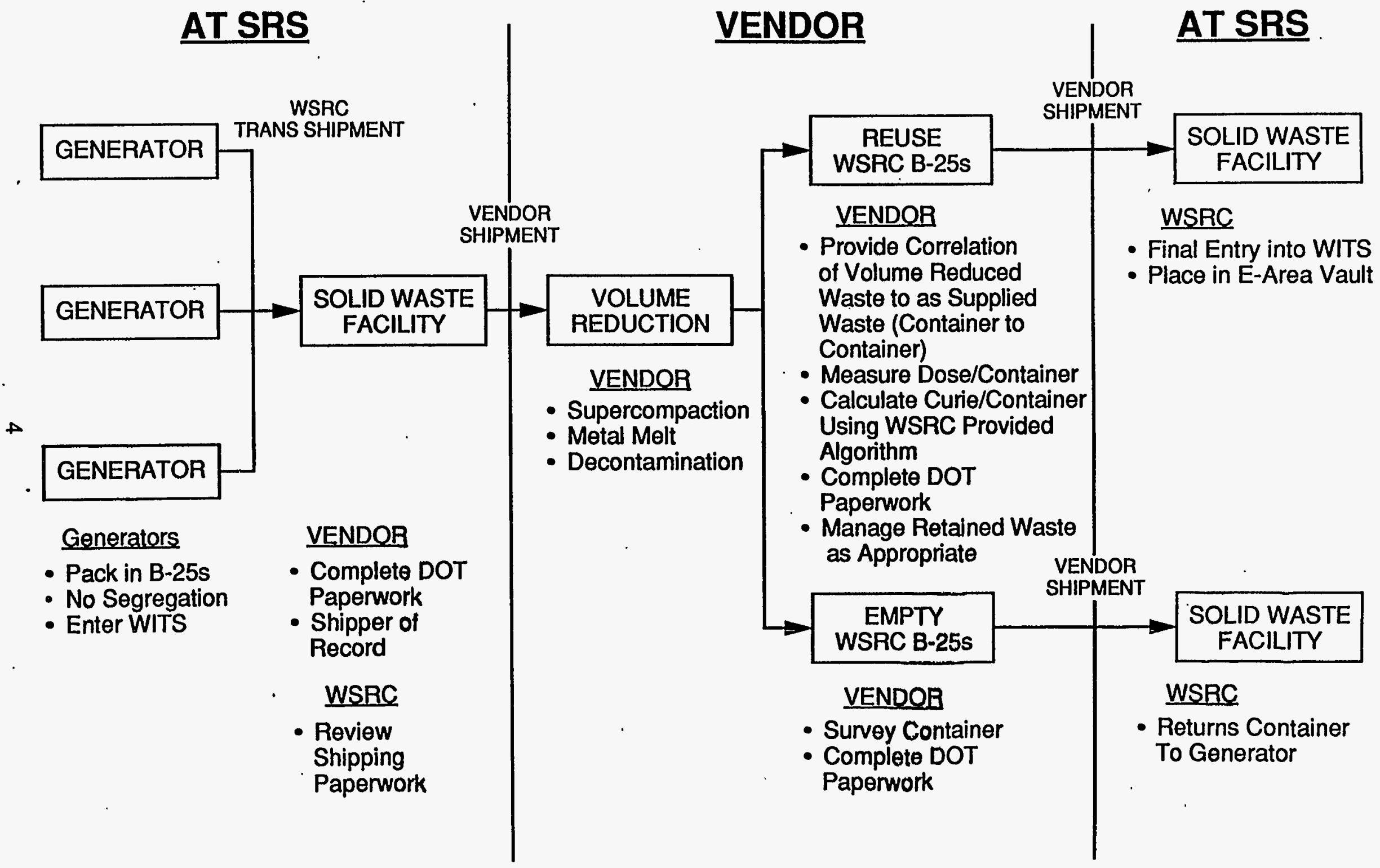

Figure 2. Flowchart of the overall process for the proposed action. 
The vendor will provide "interim" storage of the SRS LLW while awaiting the required treatment process and/or awaiting significant quantities of waste for treatment. The vendor will not store $L L W$ longer than 3 months awaiting treatment unless both the vendor's permit allows the extended length of interim on-site storage and concurrence is received from DOE. The vendor further will be responsible for the safety and security of SRS waste stored at the vendor's facility. The vendor will ensure minimum cross-contamination of the DOE-owned LLW during the period the vendor takes custody of the waste for treatment until it is returned to SRS.

The vendor will pretreat and compact SRS wastes in campaigns of only SRS wastes so as to again minimize cross-contamination. Compacted SRS wastes will be segregated from other compacted wastes. The proposed action also includes supercompacting contaminated low level radioactive asbestos. Supercompaction generally averages about an 8:1 volume reduction ratio.

Waste characterization and certification activities are essential to the operation of DOE-SR disposal facilities. The vendor will comply with requirements documented in the WSRC 1S Manual (WSRC, 1993) and such activities will be subjected to audits, inspections, and surveillances. This would enable DOE-SR and the Tennessee Department of Environment and Conservation to ensure that all safety, health physics/radiation monitoring procedures, Quality Assurance/Quality Control (QA/QC) procedures, transportation procedures, volume reduction procedures and laboratory procedures at the vendor's facility are being met.

The vendor's activities are closely scrutinized throughout the process as demonstrated by the following QA/QC requirements included in the terms of the contract:

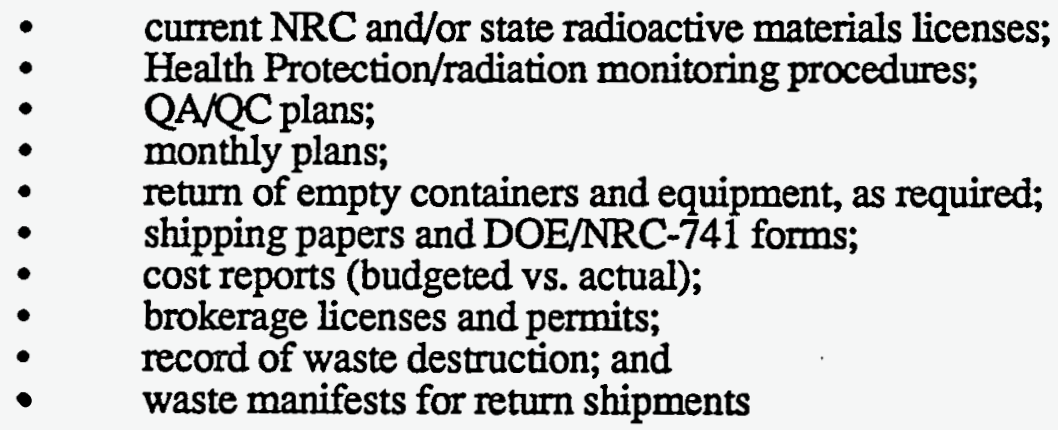

\subsection{Alternatives to the Proposed Action}

In accordance with NEPA regulations, DOE examined the following alternatives to the proposed action:

- No action, continue to use existing H-Area compactor and/or dispose in E-Area Vault

- Modify and expand the capacity of the H-Area compactor

- Construct a new waste preparation facility at SRS

\subsubsection{No Action, Continue to Use Existing.H-Area Compactors and/or Dispose in E-Area Vault}

One alternative to the proposed action is to take no action. This would consist of continuing to compact the Site's LLW at the H-Area compactor and disposal in the E-Area Vault, or containerize the LLW which cannot be compacted in the existing Site compactor and disposal in the E-Area Vault. The no-action alternative would further include awaiting the issuance of a ROD for the SRS Waste Management EIS to resolve the Site's LLW volume reduction/disposal issue. The volumes and 
waste streams to be compacted would continue to be selected consistent with the current WSRC 1S Manual acceptance criteria. This altemative would again only involve approximately one quarter of the Site's LLW during the subject time frame. The E-Area Vault would be filled during the near-term at an accelerated rate of 200 percent faster than that of the proposed action due to the disposal of uncompacted LLW. The cost of filling the remaining limited disposal capacity in the E-Area Vault with uncompacted waste would be more than three times the amount for the proposed action.

\subsubsection{Modify and Expand the Capacity of the H-Area Compactor}

A second alternative would be to modify the existing H-Area compactor to expand its capability. This modification was estimated to cost $\$ 750,000$.and would still result in the use of outdated low force compaction technology, and would not allow volume reduction of all waste streams, and would not provide the full range of capabilities that commercial facilities provide. In addition, this alternative could not be implemented within the subject time frame associated with the proposed action. This alternative was judged to be both economically and logistically unfeasible.

\subsubsection{Construct a New Waste Preparation Facility}

Another alternative would be to construct a new waste preparation facility that would provide volume reduction capacity for the site. The present scope of this alternative would not match the range of capabilities available at commercial off-site facilities (e.g., recycle and metal melt). Furthermore, this alternative is estimated to cost approximately $\$ 54$ million dollars and would not be operational within the near-term time frame being considered for the proposed action. As with the previous alternative, this alternative was determined to be both economically and logistically unfeasible.

\subsection{ENVIRONMENTAL CONSEQUENCES OF THE PROPOSED ACTION AND ALTERNATIVES}

The SRS encompasses approximately 80,535 hectares (199,000 acres) in southwestern South Carolina, approximately $40 \mathrm{~km}(25 \mathrm{mi})$ southeast of Augusta, Georgia along the Savannah River (Figure 1). SRS contains five nuclear production reactor areas; two chemical separations areas; waste processing, storage, and disposal facilities; and various supporting facilities. A comprehensive discussion of SRS and associated environs is presented in the Defense Waste Processing Facility Final Supplemental Environmental Impact Statement (DOE, 1994b), and in several SRS environmental information documents (WSRC, 1989a, 1989b; Wike et al., 1994). The most recent socioeconomic survey of the six-county SRS area of influence contains additional information (HNUS, 1992). The locations of the H-Area compactor and the Solid Waste Management Facility in E Area are depicted on Figure 1.

\subsection{Vendor Facility Operation}

Operations at the vendor facility are considered to be an ongoing activity which is beyond the scope of this EA. It can be assumed that the operation of such a permitted functioning facility could be classified as low hazard facility as per DOE Order 5481.1B. A low hazard classification is used to define facilities which, in the event of an unmitigated release of the total radiological inventory contained in that facility, would present only minor on-site and negligible off-site impacts to either people or the environment. Under the terms of the proposed contract, the vendor would be responsible for identifying and complying with all applicable laws and regulations governing the operation of the off-site facility and shipment of LLW from and back to SRS. No further impact assessments of the vendor facility were undertaken within this EA process. 


\subsection{Solid Waste Management Facility Operations}

The operation of the E-Area Vault is considered to be an ongoing activity which would not change as a result of the proposed action. The average annual worker dose at the existing E-Area Vault is 16 $\mathrm{mrem} /$ year (Hess, 1994). The Site workforce associated with the operation of the E-Area Vault is 20 employees. Neither the average annual worker dose nor the size of the subject portion of the Site workforce would be expected to change under the proposed action. No additional impacts would be expected as a result of the proposed action.

\subsection{Transportation Impacts}

\subsubsection{Analyzed Scenario}

The proposed action would include the off-site shipment of 4,503 cubic meters ( 159,000 cubic feet) of LLW generated at SRS. Waste shipments would originate at the Solid Waste Management Facility (E Area) on SRS and be sent to Oak Ridge for volume reduction by an off-site vendor. The off-site vendor in Oak Ridge was chosen for analysis within this EA since that facility has the full range of treatment capabilities included in the scope of the volume reduction needs for the subject waste. Upon completion of processing, all the waste would be transported back to SRS for disposal at the E-Area Vault. The treated LLW would be returned in three forms: supercompacted waste; metal melted and supercompacted waste; or reduced and repackaged waste.

\subsubsection{Assumptions}

Concentrations of identified isotopes were calculated based on assumed isotopic activity fractions and specific activities (Blankenhorn, 1994; Hunt, 1994). Shipping package radioactivity and truck loadings were based on container and truck physical limitations and the E-Area Vault Waste Acceptance Criteria (WSRC, 1994b). The transported LLW would be packaged in DOT strong-type containers (e.g., B-25 boxes). The shipping containers would be transported by exclusive use vehicles. Table 1 presents the number of containers per shipment and the total number of shipments for each waste form.

Both incident-free and accident radiological impacts for the shipments of low level job control waste were analyzed. Routing conditions (including population densities, distance and time traveled, and fraction of travel in various population zone types (rural, suburban, and urban)) were obtained from the HIGHWAY computer code (Johnson et. al., 1993). Table 2 shows routing conditions obtained from HIGHWAY for travel from the SRS to Oak Ridge (same route used for return trip). The commercial route selected by HIGHWAY passed through three states: South Carolina; North Carolina; and Tennessee. The information provided in that Table includes the percent of the route composed of rural, suburban and urban communities, the linear density of people along the route, and the average velocity traveled in each of the three community types. Routing conditions, dose rates, and neutron-gamma fractions were used as inputs to the computer code RADTRAN 4 (Neuhauser, 1992) to obtain radiological impacts. The exact route ultimately chosen for implementation of the proposed action would be determined by the vendor.

\subsubsection{Radiological Consequences}

Incident-Free Conditions - The magnitude of incident-free consequence depends upon the dose rate on the external surface of the transport vehicle, the exposure time and distance, and the number of people exposed. During incident-free transport, external radiation exposure would occur to the transportation workers (loading and unloading handlers and transport vehicle crew), persons sharing the transportation link at the time of shipment, and persons near the transportation link as the shipment passes. Table 3 provides the results of the incident-free analysis for transport of the various forms of the LLW. The maximally exposed individual (MEI) is located by RADTRAN at 
Table 1. Shipping Configurations and Number of Shipments by Waste Form Low-Level Waste Packages per Shipment Number of Shipments

From SRS to Oak Ridge, TN

Uncompacted 20 89

Returning to SRS

Supercompacted

Reduced \& Repackaged (to E-Area Vault)

Metal Melted \& Supercompacted

Total Return Shipments
8

8

8

43

8

5

56

Table 2. Route Information, SRS to Oak Ridge, Tennessee (from HIGHWAY)

\begin{tabular}{cccc}
\hline HIGHWAY Parameters & Rural & Suburban & Urban \\
\hline Travel Fraction & 0.64 & 0.34 & 0.02 \\
Population Distribution (people/sq km) & 14.6 & 305.6 & 1837.2 \\
Average Velocity (km/hr) & 88.5 & 40.3 & 24.2 \\
Total Distance Traveled (km) & & 540.7 & \\
\hline
\end{tabular}

approximately 30 meters from the road. Crew and handler dose calculations are based on the number of packages per shipment, the dose rate from the packages, and the average time of exposure.

Accident Consequences - Radiological consequences from an accident due to transport vehicle collision would result primarily from the release of respirable radioactive particulates and subsequent inhalation by individuals downwind of the accident, either directly or after resuspension. Other exposure pathways would include direct radiation from the cloud of airborne material and from contamination on the ground. 
Table 3. Incident-Free Transportation Impacts for LLW Shipments by Truck from and returning to SRS

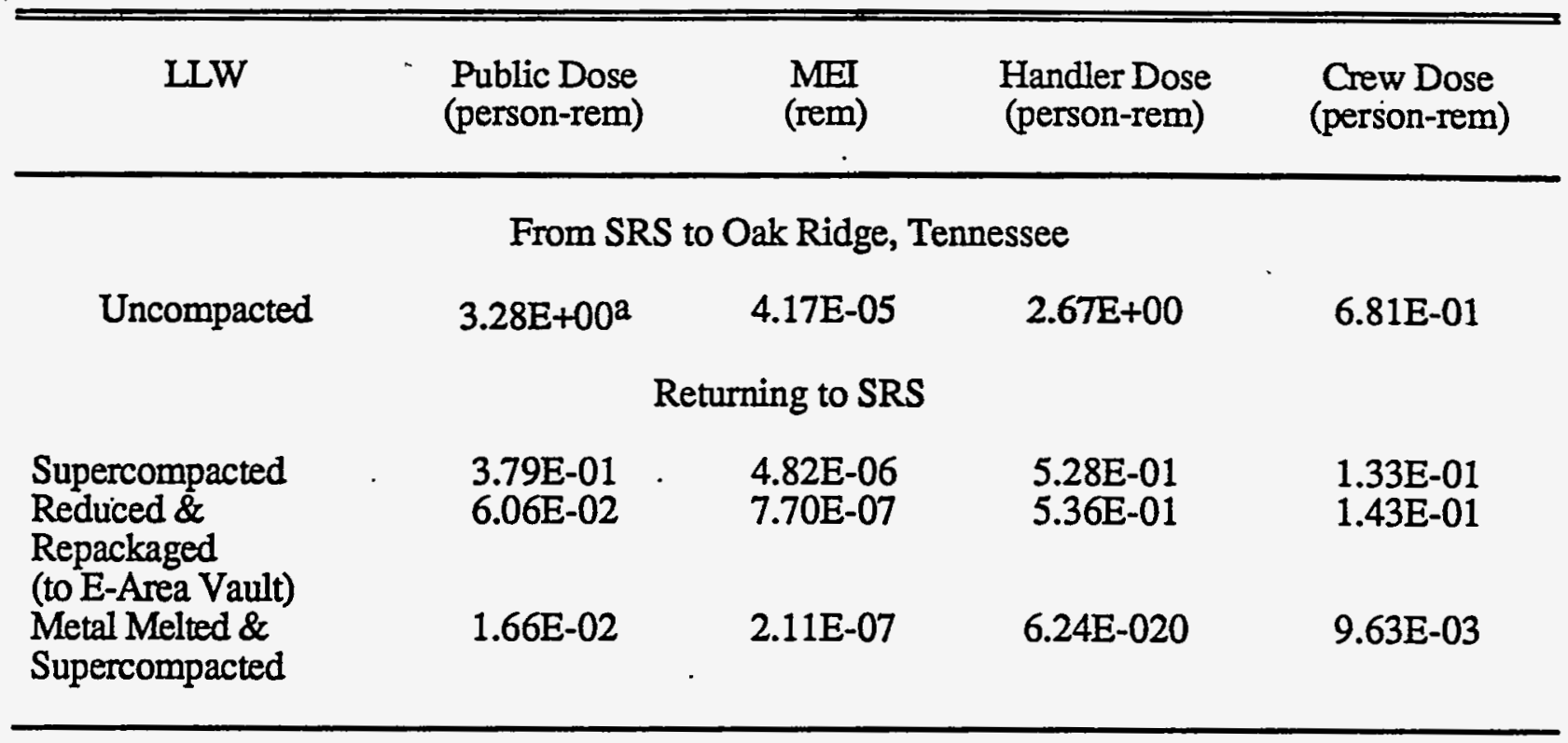

a Figures are presented in scientific notation, displaying these numbers in terms of powers of ten; e.g., the "Uncompacted" figures would be $3.28,0.0000417,2.67$, and 0.681 , respectively.

The magnitude of accident consequence is dependent upon the amount and type of radioactive material the individual(s) are exposed to, the exposure time, and the number of people exposed. NUREG-0170 (USNRC, 1977) provides criteria for determining the magnitude and probability of a given severity of an accident based on impact and thermal forces the transport vehicle and its contents could be exposed to. The highest probability for the occurrence of any accident would be for a Category I accident; however, no radioactive material would be released due to the low impact to the package. Accident probabilities for all severity categories are adapted from NUREG-0170 (HNUS, 1994). Radioactive material released is assumed to have the consistency of fine powder for inhalation modeling purposes.

Consequences of an accident depend upon the severity and population density at the location of the accident. The maximum reasonable foreseeable consequences are based on a probability of $10 \mathrm{E}-07$ or greater. Accidents with a probability of occurrence less than 10E-07 are considered not to be credible since the frequency is so low (DOE; 1994c). Table 4 presents the consequences to the public from both low consequence (high probability) and high consequence (low probability) postulated accidents.

The maximum reasonably foreseeable consequences for a potential accident would occur in an urban population zone. The least consequence (i.e., because of low population density) and higher probability (i.e., because of the larger percent of the route traversing rural areas) accident would occur in areas with a rural population. 
Table 4. Transportation Accident Impacts for LLW Shipments by Truck from and returning to SRS

\begin{tabular}{|c|c|c|c|c|}
\hline \multirow[t]{2}{*}{ LLW } & \multicolumn{2}{|c|}{ Accident Probability } & \multicolumn{2}{|c|}{$\begin{array}{l}\text { Public Dose } \\
\text { (person-rem) }\end{array}$} \\
\hline & High $^{1}$ & Low $^{2}$ & $\mathrm{High}^{3}$ & Low $^{4}$ \\
\hline \multicolumn{5}{|c|}{ From SRS to Oak Ridge, Tennessee } \\
\hline Uncompacted & $4.56 \mathrm{E}-03$ & 2.15E-06 & $1.68 \mathrm{E}-03$ & $1.28 \mathrm{E}+01$ \\
\hline \multicolumn{5}{|c|}{ Returning to SRS } \\
\hline $\begin{array}{l}\text { Supercompacted } \\
\text { Reduced \& } \\
\text { Repackaged } \\
\text { (to E-Area Vaults) } \\
\text { Metal Melted \& } \\
\text { Supercompacted }\end{array}$ & $\begin{array}{l}2.56 \mathrm{E}-03 \\
4.10 \mathrm{E}-04\end{array}$ & $\begin{array}{l}1.21 \mathrm{E}-06 \\
1.93 \mathrm{E}-07\end{array}$ & $\begin{array}{l}4.82 \mathrm{E}-02 \\
2.20 \mathrm{E}-02\end{array}$ & $\begin{array}{l}3.67 \mathrm{E}+02 \\
1.67 \mathrm{E}+02\end{array}$ \\
\hline
\end{tabular}

1 These accidents are considered to have a high probability of occurring, but the consequences would be low.

2 .These accidents are considered to have a low probability of occurring, but the consequences would be high.

${ }^{3}$ In the event of a high probability, low consequence accident, this would be the dose to the receptor group.

.4 In the event of a low probability, high consequence accident, this would be the dose to the receptor group.

Nonradiological Transportation Accidents - The nonfatal and fatal accident probabilities per shipment. for material transport along the postulated route in the analysis are calculated to be $2.49 \mathrm{E}-04$ and $1.87 \mathrm{E}-05$, respectively. The average nonfatal accident rate for vehicles is $4.6 \mathrm{E}-07$ accidents per kilometer (USNRC, 1977). The traffic fatality rate used in the analysis is from DOT (1989) data for the commercial shipping industry for trucks and is based on millions of total vehicle-kilometers of travel. DOE assumes that the percent of accidents resulting in a fatality would be the same as that for interstate travel by truck, 7.5 percent (DOT, 1989). Therefore, the traffic fatality rates in the analysis are conservatively assumed to be equal to the national average for commercial shipping.

Health Effects - Tables 3 and 4 present doses for transportation under both incident-free and accident conditions. Health effects measured as the number of latent cancer fatalities (LCFs) were 
calculated by multiplying the resultant general public consequences (low probability, high consequence) by the cancer risk factor of 5E-4 LCFs per person-rem (DOE, 1993). For individual exposures (MEI), this same value is used to calculate cancer mortality probability.

Tables 5 and 6 present the maximum calculated total incidence of latent cancers for incident-free transport and due to an accident from shipments of low level job control waste from and returning to SRS.

Table 5. Number of Latent Cancer Fatalities for Incident-Free Transportation of LLW Shipments from and to SRS

LLW $\quad \begin{gathered}\text { Potential Number of LCFs } \\ \text { (population) }\end{gathered} \quad \begin{gathered}\text { Maximum Probability for LCFs } \\ \text { (MED) }\end{gathered}$

From SRS to Oak Ridge, Tennessee

Uncompacted

Supercompacted

Reduced \& Repackaged

(to E-Area Vault)

Metal Melted \&

Supercompacted
$1.64 \mathrm{E}-03$

2.09E-08

Returning to SRS
$1.90 \mathrm{E}-04$
3.03E-05
2.41E-09
$3.85 \mathrm{E}-10$
8.30E-06
$1.06 \mathrm{E}-10$

\subsection{Environmental Consequences of the Alternatives}

The environmental consequences associated with the alternatives to the proposed action are described in the following discussion. The no-action alternative would result in a continuation of the inefficient use of the remaining disposal capacity of the E-Area Vault and the reduced operational life of that facility. In addition to increased costs, the alternative to modify and expand the capacity of the H-Area compactor would not be as efficient with respect to the near-time use of the E-Area Vault capacity. Because of the logistical problem of not being able to implement these changes to the existing facility within a short time frame, the impacts to the E-Area Vault would be essentially the same as under the no-action alternative. The construction of a new waste preparation facility would result in impacts associated with the construction and operation of a "green-field" facility. This alternative would require clearing of the project site. The proposed development site being considered for this new facility is currently a $0.02 \mathrm{sq} . \mathrm{km}$ ( 5 acre) planted pine stand located adjacent to. F. Area. No environmentally sensitive areas or natural resources such as historical or archaeological sites, endangered species or their habitats, or wetlands are present on the subject site (SRARP, 1989; SRFS, 1992; Wike et al.; 1994; LeMaster, 1995), and therefore would not be affected. However, because of the extended time frame needed to construct a new facility, the impact on the E-Area Vault would again be essentially the same as under the no-action alternative. Since the near-term logistical problems with implementation of this alternative resulted in its being 
unfeasible, operational impacts for a new waste preparation facility were not evaluated within the context of this EA.

Table 6. Maximum Number of Potential Latent Cancer Fatalities from Accidents for LLW Shipments from and to SRS

From SRS to Oak Ridge, Tennessee
Uncompacted
6.40E-03

Returning to SRS

Supercompacted

1.84E-01

Reduced \& Repackaged

8.35E-02

(to E-Area Vault)

Metal Melted \& Supercompacted

1.33E-11

\subsection{Cumulative Impacts}

The principal cumulative impacts from the proposed action would be those associated with an increased capacity in the E-Area Vault of twelve percent over the other alternatives during the subject time frame. The interim shutdown of the H-Area compactor would have a negligible impact on the volume of Site electrical use. There would be no change in the Site workforce. No latent cancer fatalities would be expected to result from the proposed action.

\subsection{REgULATORY AND PERMITTING PROVISIONS CONSIDERED}

DOE policy is to carry out its operations in compliance with all applicable Federal, state, and local laws and regulations, as well as all DOE Orders. This section provides a discussion of the major regulatory permit programs that might be applicable to the proposed action.

\subsection{National Environmental Policy Act of 1969 as amended}

This EA has been prepared in compliance with the NEPA of 1969, as amended, and the requirements of the CEQ Regulations for Implementing NEPA (40 CFR Parts 1500-1508), and DOE Regulations (10 CFR Part 1021), and DOE Order 5440.1E. NEPA, as amended, requires "all agencies of the Federal Government" to prepare a detailed statement on the environmental effects of proposed "major Federal actions significantly affecting the quality of the human environment." This EA has been written to comply with NEPA and assess the potential environmental impacts of off-site volume reduction by supercompaction, metal melt, and/or decontamination of LLW generated at SRS. 


\subsection{Waste Shipment Regulations}

The vendor must comply with DOT regulation 49 CFR 173 for shipments of radioactive materials and any applicable state regulations for transportation of radioactive materials. The vendor must pass a pre-trip inspection checklist in conformance with the requirements of the Federal Motor Carrier Safety Regulations (49 CFR 390-399). In addition, any empty shipping containers would as much as reasonably practical be in compliance with 49 CFR 173.427 (a) - (e).

\subsection{Site LLW Regulations}

The vendor must be in compliance with the Site E-Area Vault Waste Acceptance Criteria in the WSRC 1S Manual (WSRC, 1993) and the DOE Radiological Control Manual (DOE, 1994a), and any applicable NRC and state radioactive materials licenses. 


\subsection{REFERENCES}

Blankenhorn, J. A., 1994. Interoffice Memorandum to L. C. Thomas, Waste Management Environmental Impact Statement Waste Streams (U), SWE-SWO-94-0200, Westinghouse Savannah River Company, Aiken, South Carolina.

DOE (U. S. Department of Energy), 1993. Recommendations for the Preparation of Environmental Assessments and Environmental Impact Statements, Office of NEPA Oversight (EH-25) U. S. Department of Energy, Washington, District of Columbia.

DOE (U. S. Department of Energy), 1994a. DOE Radiological Control Manual, Savannah River Operations Office, Aiken, South Carolina.

DOE (U. S. Department of Energy), 1994b. Final Supplemental Environmental Impact Statement - Defense Waste Processing Facility DOE/EIS-0082-S, Savannah River Operations Office, Aiken, South Carolina.

DOE (U. S. Department of Energy), 1994c. Framework for Assessing the Effects of Radioactive Materials Transportation in Defense Programs NEPA Documents Defense Programs Office of Environmental Support, U. S. Department of Energy, Washington, District of Columbia.

DOE (U. S. Department of Energy), 1995. Draft Environmental Impact Statement for Waste Management at the Savarinah River Site, Vol. I and II DOE/EIS-0217D, Savannah River Operations Office, Aiken, South Carolina.

DOT (U. S. Department of Transportation), 1989. Accidents Reported by Motor Carriers of Property 1989, FHWA/MC-92/018, U.S. Department of Transportation, Federal Highway Administration, Office of Motor Carriers, Washington, District of Columbia.

Hess, M. L., 1994. WSRC Data Transmittal to H. L. Pope, Annual Worker Dose by Facility, ESH-NEP-94-0160, Westinghouse Savannah River Company, Aiken, South Carolina.

HNUS (Halliburton NUS Environmental Corporation), 1992. Socioeconomic Characteristics of Selected Counties and Communities Adjacent to the Savannah River Site, July 1992, Halliburton NUS Corporation, Aiken, South Carolina.

HNUS (Halliburton NUS Environmental Corporation), 1994. Transportation Radiological Analysis - Savannah River Site Pu-238 Processing Environmental Assessment, Aiken, South Carolina.

Hunt, P. D., 1994, Interoffice Memorandum to R. C. Shank, 1027 Hazard Categorization Re-Evaluation, SWE-SWO-94-0176, April 7, Westinghouse Savannah River Company, Aiken, South Carolina.

Johnson, P. E., D. S. Joy, D. B. Clarke, and J. M. Jacobi, 1993. Highway 3.1 - An Enhanced Highway Routing Model: Program Description, Methodology, and Revised User's Manual, ORNL/TM-12124, U.S. Department of Energy, Washington, District of Columbia.

LeMaster, E., 1995. Protected Species Survey for the Proposed Waste Management Expansion in the Uncleared Portion of E-Area on SRS. Savannah River Forest Station, New Ellenton, South Carolina. 
Neuhauser, K. S. and F. L. Kanipe, 1992. RADTRAN 4: Volume 3 User Guide, SAND89-2370; TTC-0943; UC-722, Sandia National Laboratories, Aibuquerque, New Mexico.

SRARP (Savannah River Archaeological Research Program), 1989. Archaeological Resource Management Plan of the Savannah River Archaeological Research Program. Savannah River Archaeological Research Program, South Carolina Institute of Archaeology and Anthropology, University of South Carolina, Aiken, South Carolina.

SRFS (Savannah River Forest Station), 1992. Savannah River Site Proposed, Threatened, Endangered, and Sensitive Plants and Animals. Savannah River Forest Station, New Ellenton, South Carolina.

USNRC (U.S. Nuclear Regulatory Commission), 1977. Final Environmental Impact Statement on the Transportation of Radioactive Material by Air and Other Modes, NUREG-0170, U.S. Nuclear Regulatory Commission, Washington, District of Columbia.

WSRC (Westinghouse Savannah River Company), 1989a. Reactor Operation Environmental Information Document, Volume I: Geology, Seismology and Subsurface Hydrology (U), WSRC-89-815, Westinghouse Savannah River Company, Savannah River Site, Aiken, South Carolina.

WSRC (Westinghouse Savannah River Company), 1989b. Reactor Operation Environmental Information Document, Volume III: Meteorology, Surface Hydrology, Transport and Impacts (U), WSRC-89-817, Westinghouse Savannah River Company, Savannah River Site, Aiken, South Carolina.

WSRC (Westinghouse Savannah River Company), 1990. WSRC Administrative Procedural Control System for SRS Reactor and Non-reactor Nuclear Facilities, 11Q Manual, Westinghouse Savannah River Company, Aiken, South Carolina.

WSRC (Westinghouse Savannah River Company), 1993. SRS Waste Acceptance Criteria - Manual, 1S Manual, Westinghouse Savannah River Company, Aiken, South Carolina.

WSRC (Westinghouse Savannah River Company), 1994a. Thirty-Year Solid Waste Generation Forecast at SRS, Revision 4, July 1994, WSRC-RP-94-532, Westinghouse Savannah River Company, Aiken, South Carolina.

WSRC (Westinghouse Savannah River Company), 1994b. Savannah River Site Waste Acceptance Criteria Manual (U), E-Area Vaults Low-Level Radioactive Solid Waste Acceptance Criteria, WSRC-1S, WAC 3.10, Rev.1., Westinghouse Savannah River Company, Aiken, South Carolina

Wike, L. D., R. W. Shipley, A. L. Bryan, J. A. Bowers, C. L. Cummins, B. R. del Carmen, G. P. Friday, J. E. Irwin, J. J. Mayer, E. A. Nelson, M. H. Paller, V. A. Rogers, W. L. Specht, and E. W. Wilde, 1994. SRS Ecology: Environmental Information Document, WSRC-TR-93-496, Westinghouse Savannah River Company, Savannah River Site, Aiken, South Carolina. 


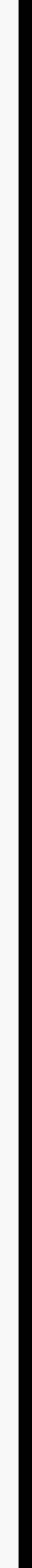

